\title{
Full Title: Neuropsychiatric Events Associated with Leukotriene-modifying Agents: A Systematic Review
}

\section{Running Title: Neuropsychiatric Events Associated with Leukotriene-modifying Agents}

Sharon W. Y. Law ${ }^{1}$, Angel Y. S. Wong ${ }^{1}$, Shweta Anand ${ }^{1}$, Ian C. K. Wong ${ }^{1,2}$, Esther W. Chan ${ }^{1}$

\section{Affiliations}

${ }^{1}$ Centre for Safe Medication Practice and Research, Department of Pharmacology and Pharmacy, Li Ka Shing Faculty of Medicine, The University of Hong Kong, Office 02-08, 2/F Laboratory Block, 21 Sassoon Road,

Hong Kong SAR, China

${ }^{2}$ Research Department of Practice and Policy, School of Pharmacy, University College London, 29-39

Brunswick Square, London WC1N 1AX, United Kingdom

\section{Corresponding Author}

Esther W. Chan

Centre for Safe Medication Practice and Research, Department of Pharmacology and Pharmacy,

Li Ka Shing Faculty of Medicine, The University of Hong Kong,

Office 02-08, 2/F Laboratory Block, 21 Sassoon Road,

Hong Kong SAR, China

Email: ewchan@hku.hk

Telephone: +85228315110

\section{Acknowledgements}

We thank Joseph E. Blais (Centre for Safe Medication Practice and Research) for proofreading the manuscript. 


\begin{abstract}
Introduction Leukotriene-modifying agents (LTMAs) including montelukast, zafirlukast, and zileuton are approved by the U.S. Food and Drug Administration (FDA) for the treatment of asthma and allergic rhinitis. Various neuropsychiatric events (NEs) have been reported; however, the evidence of the association is conflicting. This systematic review investigates the association between NEs and LTMAs by assessing the relevant published literature.
\end{abstract}

Methods PubMed, EMBASE, MEDLINE, and Cochrane Library were searched using keywords. Studies designed to investigate the association were eligible for inclusion without restriction to any study design or language. The primary outcome was defined as suicidal conditions while secondary outcomes included all other NEs.

Results Thirty-three studies were included for a narrative review. Four observational studies did not find a significant association while 10 pharmacovigilance studies using different global databases detected the signals. Notably, some studies suggest that the FDA warning issued in 2008 might have influenced the reporting rate of NEs due to increased awareness.

Limitations The risk of NEs was not quantified due to the lack of randomized controlled trials and observational studies investigating the association.

Conclusion Many pharmacovigilance studies have been conducted to determine the association between NEs and LTMAs but there is limited evidence from observational studies. High quality epidemiological studies should be conducted to evaluate the association and quantify the risk, not only in children but also in adults.

\title{
Key Points
}

- Observational studies did not find a significant association between neuropsychiatric evnets (NEs) and leukotriene-modifying agents (LTMAs).

- Many pharmacovigilance studies detected the signal of NEs during LTMA treatment.

- The warning issued by the U.S. Food and Drug Administration might have influenced the reporting rate of NEs. 


\section{Introduction}

Montelukast, zafirlukast, and zileuton are leukotriene-modifying agents (LTMAs) approved by the U.S. Food and Drug Administration (FDA) in late 1990s for the prophylaxis and chronic treatment of asthma [1-3]. Montelukast is further indicated for the prevention of exercise-induced bronchoconstriction and relief of symptoms of allergic rhinitis and it can be used in children as young as 6 months for the latter indication [3]. With the once-daily dosing regimen, ease of administration and good safety profile, montelukast is the most widely prescribed LTMA. However, various neuropsychiatric events (NEs) have been reported with the use of LTMAs over the past two decades [4-13].

Based on the results of post-marketing pharmacovigilance studies, the FDA issued a warning about the association and alerted the healthcare professionals in 2008 [14]. NEs including agitation, aggressive behavior or hostility, anxiousness, depression, disorientation, disturbance in attention, dream abnormalities, hallucinations, insomnia, irritability, memory impairment, restlessness, somnambulism, suicidal ideation and behavior (including suicide), and tremor were added to the package labels of LTMAs more than ten years after the medications were launched $[1-3,14]$. Nonetheless, the concerns about the neuropsychiatric safety of LTMAs in children was raised again recently due to cases reported in the Australian media [15]. Parents complained that they were not warned of the possible association when they received the medications [15]. However, the evidence of the association between NEs and LTMAs has been conflicting and the risk has not been quantified in previous studies [16-20].

Literature reviews and analyses were conducted based on the results of randomized controlled trials (RCTs) [1619]; however, NEs are rare outcomes and they are difficult to detect in RCTs that have a short follow-up and relatively small sample size. Observational studies could complement the findings of RCTs since they have greater generalisability and longer follow-up time. With the concerns about the neuropsychiatric safety of LTMAs, some observational and pharmacovigilance studies were conducted to examine this association [4-13, 21-24]. This review aims to systematically evaluate the evidence from the published literature of different study designs to investigate the association between NEs and LTMAs.

\section{Method}

\subsection{Search Strategy}

This systematic review was conducted according to the study protocol that is available on the website of the Centre for Safe Medication Practice and Research (http://www.pharma.hku.hk/sweb/CSMPR/). Four databases, 
including PubMed, EMBASE, MEDLINE, and Cochrane Library, were searched on 16 November, 2016 to locate relevant literature using keywords, $\mathrm{MeSH}$, and Emtree which are related to the drugs of interest and various NEs. The bibliography of the retrieved articles was manually screened to further expand the search for study inclusion. The detailed search strategy for each database is shown in supplementary material 1.

\subsection{Inclusion and Exclusion Criteria}

All published studies which were designed to investigate the association between NEs and LTMAs were eligible for selection without restriction to any study design or language. Online translation tools were used if the article was written in a language other than Chinese or English. To assess for publication bias, conference abstracts were considered to be eligible in this review. The population of interest were patients of all ages who were exposed to any LTMA for any indication. Animal studies were excluded. In addition, we excluded the older studies if more than one studies with the same data source, study period, and outcomes of interest were identified.

\subsection{Data Collection}

Citations and abstracts of the search results were stored in Endnote X7 for evaluation and selection. To reduce selection bias, all titles and abstracts were screened by two independent reviewers (SWYL, AYSW) according to the eligibility criteria. Any discrepancy was resolved by consensus. PICO items including the data source of the study, type of study design, demographics of participants, intervention (specific LTMA used, dose and duration of treatment), outcomes of interest (neuropsychiatric events), follow-up time, sample size, and covariates for adjustment were extracted and compiled in a data extraction form.

Due to the clinical importance, the primary outcome of interest was defined as suicidal conditions, including completed suicide, suicide attempt, suicidal ideation, and self-harm either presented separately or as a combined outcome. The rare occurance of suicidal conditions was evaluated as a separate outcome. Secondary outcomes included other NEs such as hallucinations, psychosis, personality disorders, agitation, hostility, irritability, depression, anxiety, mood disorders, hyperactivity, cognitive impairment, sleep disorders, dream abnormalities, seizure, and tremor to further inform the overall neuropsychiatric safety profile of LTMAs.

\subsection{Quality Assessment}

The quality of the included studies was assessed independently by two reviewers (SWYL, AYSW). The Newcastle-Ottawa scale was used to assess the methodology of the included observational studies. Due to the lack of standard assessment tools for interrupted time series (ITS) analysis, pharmacovigilance studies, case series, and 
case reports, these findings were narratively described. The quality of the studies from conference abstracts was not assessed in this review as information on methods was limited.

\section{Results}

\subsection{Search Results}

Thirty-three studies, including two non-English studies $[12,25]$, were selected for a narrative review. The study types include cohort studies $(n=2)[21,23]$, nested case-control studies $(n=2)[22,24]$, pharmacovigilance studies $(n=10)$ [4-13], ITS analysis $(n=2)$ [26, 27], case series $(n=1)$ [28], case reports $(n=6)$ [29-34], review of case reports $(n=1)$ [25], and conference abstracts $(n=9)$ [35-43]. Of the included articles, twelve studies reported suicidal conditions as one of the outcomes $[6,10,11,21-23,25,26,32,36,37,40]$. The PRISMA flow diagram of the review is shown in Fig. 1.

\subsection{Methodological Quality of Observational Studies}

For methodological quality, one cohort study scored relatively high as the selection of cohort demonstrated representativeness [23]. However, only a subgroup analysis was performed regarding montelukast and the comparison was based on the cumulative defined daily dose but not between exposed and unexposed groups. Adjustment was made in accordance with the possible confounders but the severity of asthma was not considered. The outcome was assessed adequately but the loss of follow-up was not reported [23]. Jick et al. resulted in a low score as they did not demonstrate a high quality of cohort selection, comparability, and outcome measurement [21]. The follow-up period was not specified and no appropriate unexposed group was used for risk comparison [21].

The overall quality of two nested case-control studies $[22,24]$ was high in terms of the sample selection, comparability, and exposure. Adequate adjustment for the covariates was made in both studies with Ali et al. [24] adjusting the analysis for socioeconomic status overcoming the limitation identified in Schumock et al. study [22]. Quality assessment results are presented in supplementary material 7 and 8.

\subsection{NEs Associated with LTMAs}

Owing to the heterogeneity of different study designs, the results could not be pooled in a meta-analysis. Two nested case-control studies were identified but they originated from the same data source [22, 24]; therefore, metaanalysis was not conducted. This narrative review is structured based on study designs and outcomes. Table 1 and 
2 summarize the characteristics of the included analytic studies and pharmacovigilance studies respectively while supplementary material 2 to 6 summarize the case series, case reports, reviews, and conference abstracts.

\subsubsection{Observational Studies}

Regarding the primary outcome, two cohort studies did not find a significant association between montelukast and suicidal conditions [21, 23]. One case of suicide in Jick et al. cohort occurred two years after a short course of (28 days) montelukast and was not considered to be related to the medication exposure [21]. The lack of outcome occurrence may be due to rare events, inadequate sample size and a short follow-up period. Chen et al. investigated the association between asthma and self-harm instead of the association with LTMAs [23]. However, the association between self-harm and montelukast was assessed in the subgroup analysis by the cumulative defined daily dose. No increased risk of self-harm was found (adjusted hazard ratio [HR] 0.92, 95\% confidence interval [CI] 0.29-2.91) for the higher dose versus the lower dose [23]. Of note, cases of completed suicide were excluded from the study cohort with only self-harm included as the outcome [23].

Two nested case-control studies from the same data source were identified but only Schumock et al. investigated the association between suicide attempt and LTMAs $[22,24]$. The adjusted odds ratio (OR) was 0.70 (95\% CI 0.36-1.39) which showed a potential risk reduction but the results were not statistically significant [22]. On the contrary, a stratified analysis for the 19 to 24-year age group showed an increased risk but the CI was wide (adjusted OR 5.15, 95\% CI 1.16-22.86) [22]. Notably, the study focused on asthmatic children and young adults only. The results were also mainly driven by montelukast due to its frequent use in clinical practice when compared to other LTMAs, with 233 over 238 subjects on montelukast in the study [22].

For the secondary outcomes, only one observational study evaluated the composite of NEs associated with montelukast in children with asthma [24]. Subgroup analyses were conducted based on the cumulative dose, treatment duration, and recency of exposure. The adjusted OR for any exposure to montelukast in the past year was 1.01 (95\% CI 0.88-1.14) [24]. Post hoc analyses were conducted for different types of NEs. Among all cases, adjustment disorders (adjusted OR 1.34, 95\% CI 0.99-1.79) were the most commonly seen NEs, followed by attention deficit disorder/attention deficit hyperactivity disorder (adjusted OR 1.07, 95\% CI 0.80-1.44) [24]. No consistent significant positive association was found in the study. 


\subsubsection{Interrupted Time Series Analysis}

Two studies using ITS analysis were included in this review [26, 27]. Zhou et al. used the dispensing records of antidepressants as a surrogate for NEs [27]. They found a significant increase in the dispensing rate of antidepressants in patients aged between 18 and 24 years after starting montelukast [27]. However, the effect was also found to be statistically significant in the comparison groups which included fluticasone and long-acting betaagonist with inhaled corticosteroid (LABA/ICS). The authors concluded that NEs were not associated with the use of montelukast [27].

The change in the reporting rate of NEs before and after the FDA warning was investigated in the other ITS analysis conducted by Lu et al. [26]. They found an increase in mental health visits among adolescents and adults after the FDA warning was issued [26]. An increase in suicide attempts was also detected among young adults [26]. In light of these findings, it was suggested that the FDA warning may have raised awareness and increased the reporting of mental health symptoms [26]. 


\begin{tabular}{|c|c|c|c|c|c|c|c|c|c|c|c|}
\hline Study & $\begin{array}{l}\text { Study } \\
\text { design }\end{array}$ & Region & $\begin{array}{l}\text { Data } \\
\text { source }\end{array}$ & $\begin{array}{l}\text { Study } \\
\text { period }\end{array}$ & Inclusion criteria & Exclusion criteria & Exposure & $\begin{array}{l}\text { Number of } \\
\text { subjects }\end{array}$ & $\begin{array}{l}\text { Follow- } \\
\text { up }\end{array}$ & Covariates & Results and outcomes of interest \\
\hline $\begin{array}{l}\text { Jick et al. } \\
{[21]}\end{array}$ & Cohort & $\begin{array}{l}\text { United } \\
\text { Kingdom }\end{array}$ & GPRD & $\begin{array}{l}\text { Feb 1998- } \\
\text { Mar } 2007\end{array}$ & $\geq 1$ prescriptions of $\mathrm{M}$ & --- & M & $\begin{array}{l}23500 \\
\text { No unexposed } \\
\text { group }\end{array}$ & --- & --- & $\begin{array}{l}\text { Rate of suicide } \\
\text { Number of suicides in } 21050 \text { person-years at } \\
\text { risk }=0\end{array}$ \\
\hline $\begin{array}{l}\text { Chen et } \\
\text { al. [23] }\end{array}$ & Cohort & Taiwan & $\begin{array}{l}\text { National } \\
\text { Health } \\
\text { Insurance } \\
\text { Research } \\
\text { Database }\end{array}$ & $2000-2008$ & $\begin{array}{l}\text { Aged }>10 \text { years with } \\
\text { inpatient diagnosis } \\
\text { and/or } \geq 2 \text { recorded } \\
\text { diagnoses and } 1 \text { year } \\
\text { duration of asthma in } \\
\text { outpatient setting }\end{array}$ & $\begin{array}{l}\text { Completed suicide } \\
\text { (Deaths within } 2 \text { weeks } \\
\text { of self-harm) }\end{array}$ & M & $\begin{array}{l}\text { cDDD 0-90: } \\
726 \\
\text { cDDD } \geq 90: \\
165960\end{array}$ & $\begin{array}{l}\text { Mean: } \\
5.84 \\
\text { years }\end{array}$ & $\begin{array}{l}\text { Age, sex, area of residence, } \\
\text { insurance premium, } \\
\text { episode of psychiatric } \\
\text { disease, } M \text { and } \\
\text { Charlson comorbidity } \\
\text { index }\end{array}$ & $\begin{array}{l}\text { Self-harm } \\
\text { Adjusted } \mathrm{HR}^{\mathrm{a}}=0.92(95 \% \text { CI } 0.29-2.91)\end{array}$ \\
\hline $\begin{array}{l}\text { Schumock } \\
\text { et al. [22] }\end{array}$ & $\begin{array}{l}\text { Nested } \\
\text { case- } \\
\text { control }\end{array}$ & $\begin{array}{l}\text { United } \\
\text { States }\end{array}$ & $\begin{array}{l}\text { LifeLink } \\
\text { Health Plan } \\
\text { Claims } \\
\text { Database }\end{array}$ & 1997-2006 & $\begin{array}{l}\text { Aged 5-24 years with } \\
\geq 1 \text { prescriptions of an } \\
\text { asthma controller } \\
\text { medication }\end{array}$ & $\begin{array}{l}\text { Index date } \geq 30 \text { days } \\
\text { before asthma diagnosis, } \\
\text { last enrolment date } \\
\leq \text { index date, not } \\
\text { continuously enrolled for } \\
\geq 6 \text { months, or } \\
\text { significant gaps of } \\
\text { enrolment for } \geq 2 \text { months }\end{array}$ & LTMAs & $\begin{array}{l}\text { Case: } 344 \\
\text { Control: } 3438\end{array}$ & 180 days & $\begin{array}{l}\text { Asthma severity, } \\
\text { comorbidities associated } \\
\text { with a higher risk of SA, } \\
\text { previous SA/psychological } \\
\text { counselling, and } \\
\text { current/past use of } \\
\text { medications with increased } \\
\text { risk of suicide }\end{array}$ & $\begin{array}{l}\text { SA } \\
\text { Adjusted OR }=0.70(95 \% \text { CI } 0.36-1.39)\end{array}$ \\
\hline $\begin{array}{l}\text { Ali et al. } \\
\text { [24] }\end{array}$ & $\begin{array}{l}\text { Nested } \\
\text { case- } \\
\text { control }\end{array}$ & $\begin{array}{l}\text { United } \\
\text { States }\end{array}$ & $\begin{array}{l}\text { LifeLink } \\
\text { Health Plan } \\
\text { Claims } \\
\text { Database }\end{array}$ & 1998-2009 & $\begin{array}{l}\text { Aged } 1-17 \text { years with } \\
\text { a primary diagnosis of } \\
\text { asthma, and health } \\
\text { plan and pharmacy } \\
\text { benefit eligibility } 12 \\
\text { months before and } \\
\text { after the asthma claim }\end{array}$ & $\begin{array}{l}\text { Developmental or } \\
\text { pervasive developmental } \\
\text { disorder, receiving long- } \\
\text { term care, or pre-existing } \\
\text { NEs } 365 \text { days before } \\
\text { asthma claim }\end{array}$ & M & $\begin{array}{l}\text { Case: } 1920 \\
\text { Control: } 5760\end{array}$ & 365 days & $\begin{array}{l}\text { Asthma severity, factors } \\
\text { prognostic of psychiatric } \\
\text { disorders, and low socio- } \\
\text { economic status }\end{array}$ & $\begin{array}{l}\text { NEs } \\
\text { Adjusted OR }=1.01 \text { (95\% CI 0.88-1.14) }\end{array}$ \\
\hline $\begin{array}{l}\text { Zhou et } \\
\text { al. [27] }\end{array}$ & ITS & $\begin{array}{l}\text { United } \\
\text { States }\end{array}$ & $\begin{array}{l}\text { Wolters } \\
\text { Kluwer's } \\
\text { SOURCE } \\
\text { Lx } \\
\text { pharmacy } \\
\text { claims } \\
\text { database }\end{array}$ & 2003-2007 & $\begin{array}{l}\text { Aged } \leq 45 \text { years with } \\
\geq 2 \text { prescriptions of } \mathrm{M} \\
\text { and had } \geq 1 \text { medical/ } \\
\text { pharmacy claim } 12 \\
\text { months before and } 12 \\
\text { months after the index } \\
\text { date }\end{array}$ & $\begin{array}{l}\text { Had other asthma } \\
\text { controller medications } \\
12 \text { months before and } 3 \\
\text { months after the index } \\
\text { date }\end{array}$ & M & $\begin{array}{l}\text { M: } 232159 \\
\text { F: } 264704 \\
\text { LABA/ICS: } \\
89635\end{array}$ & 180 days & --- & $\begin{array}{l}\text { Antidepressant dispensing rate after initiating } \\
\text { the medication } \\
\text { 1) Patient aged } 12-17 \text { years }^{\mathrm{b}} \text { : } \\
\text { M }(0.80 \%, 95 \% \text { CI } 0.31-1.29 \%, p<0.001) \text {, } \\
\text { F }(0.83 \%, 95 \% \text { CI }-0.08-1.73 \%) \text {, } \\
\text { LABA/ICS }(0.76 \%, 95 \% \text { CI } 0.22-1.30 \%, p \\
<0.05) \\
\text { 2) Patients aged } 18-24 \text { years }: \\
\text { M }(1.93 \%, 95 \% \text { CI } 1.55-2.32 \%, p<0.001) \text {, } \\
\text { F }(1.72 \%, 95 \% \text { CI } 1.30-2.15 \%, p<0.001) \text {, } \\
\text { LABA/ICS }(2.76 \%, 95 \% \text { CI } 2.35-3.17 \%, p \\
<0.001)\end{array}$ \\
\hline $\begin{array}{l}\text { Lu et al. } \\
{[26]}\end{array}$ & ITS & $\begin{array}{l}\text { United } \\
\text { States }\end{array}$ & $\begin{array}{l}\text { Population- } \\
\text { based } \\
\text { Effectivene } \\
\text { ss in } \\
\text { Asthma and } \\
\text { Lung } \\
\text { Diseases } \\
\text { Network }\end{array}$ & 2005-2010 & $\begin{array}{l}\text { Aged 5-64 years with } \\
\geq 1 \text { outpatient or } \\
\text { inpatient visit with a } \\
\text { diagnosis of asthma } \\
\text { and continuous } \\
\text { enrolment in the past } \\
12 \text { months (rolling } \\
\text { cohort) }\end{array}$ & $\begin{array}{l}\text { History of COPD, cystic } \\
\text { fibrosis, bronchiectasis, } \\
\text { pulmonary } \\
\text { hypertension/ embolism; } \\
\text { bronchopulmonary } \\
\text { dysplasia; or CHF in the } \\
\text { past } 12 \text { months }\end{array}$ & LTMAs & 140,000 & $\begin{array}{l}18 \\
\text { months }\end{array}$ & --- & $\begin{array}{l}\text { Immediate impact on MHV and SA after the } \\
\text { FDA warning } \\
\text { 1) Patients aged 5-17 years } \\
\text { MHV (0.25\%, 95\% CI 0.01-0.49\%, } p= \\
\text { 0.0454); SA (0) } \\
\text { 2) Patients aged 18-29 years } \\
\text { MHV (0); SA ( } 0.03 \%, 95 \% \text { CI } 0.01-0.05 \% \text {, } \\
p=0.0032) \\
\text { 3) Patients aged 30-64 years } \\
\text { MHV (0.61\%, } 95 \% \text { CI } 0.30-0.91 \%, p= \\
0.0002) \text {; SA (0) }\end{array}$ \\
\hline
\end{tabular}

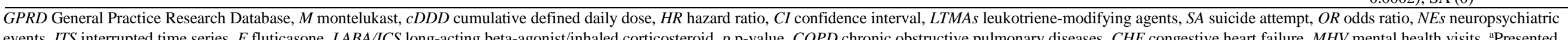
as the subgroup analysis by comparing the cumulative defined daily dose. ' 


\subsubsection{Pharmacovigilance Studies}

Pharmacovigilance studies cannot quantify the risks but they can be used to detect signals, especially when rare adverse drug reactions (ADRs) cannot be identified in the RCTs. Ten studies investigating ADRs that implicated LTMA use were included [4-13]. They were conducted using different databases worldwide including the Drug Safety Research Unit from the United Kingdom [4, 5], the Swedish Drug Information System (SWEDIS) from Sweden [6, 7], the Spanish System of Pharmacovigilance from Spain [13], the Food and Drug Administration Adverse Event Reporting System (FAERS) from the United States [11], the French Pharmacovigilance Database (FPVD) from France [9, 12], the EudraVigilance (EV) from European Union (EU) [8], and the Vigibase from the World Health Organization (WHO) [10]. Almost half of the studies only included patients aged less than 18 years $[6-8,10]$ and most of them focused mainly on ADRs related to montelukast $[4,6-10,12,13]$.

The rate of suicidal conditions was investigated in three pharmacovigilance studies $[6,10,11]$. Bygdell et al. reported one case of suicidal condition that implicated the use of montelukast in the SWEDIS during a 10-year period [6]. Schumock et al. conducted another study based on the FAERS in 1999-2009 and found that 105 completed suicides involved the use of LTMAs, with $96 \%$ of the reports relating to the use of montelukast [11]. The suicide rate was calculated based on the number of dispensed prescriptions. The result was compared with short-acting beta-agonists (SABAs), which are the first-line treatment of asthma; and selective serotonin reuptake inhibitors (SSRIs), which are likely associated with suicide [11]. The suicide rate for montelukast was higher than for SABAs but lower than for SSRIs [11]. Notably, comparing the rates before and after the warning issued by the FDA, the post warning rate was higher than that in the pre-warning period [11]. This finding is consistent with the aforementioned ITS analysis [26], which suggested that the warning may have increased the reporting rate. Aldea-Perona et al. reported a total of 674 ADRs of suicidal and self-injurious behavior ( $26 \%$ of all ADRs) possibly associated with montelukast from the Vigibase [10]. Suicidal conditions also predominated in adolescents aged between 12 to 17 years with positive de-challenge and re-challenge demonstrated in some cases [10].

Biswas et al. detected NEs from users of montelukast and found 36 cases of insomnia, 10 cases of drowsiness and 5 cases of depression [4]. Twaites et al. did a subsequent study using the same data source but on a different LTMA, zafirlukast [5]. Seventy-nine cases of depression were reported which accounted for $1 \%$ of the cohort [5]. However, the incidence density difference was -1.1 (99\% CI, -2.4-0.3) [5]. Two pharmacovigilance studies were conducted based on the SWEDIS but in different study periods so both were included [6,7]. Forty-eight and 60 
psychiatric ADR reports of children taking montelukast were identified by Wallerstedt et al. and Bygdell et al. respectively $[6,7]$. The main NEs were nightmares, sleep disorders, anxiety, and aggressiveness.

Cereza et al. searched the Spanish database and retrieved 24 reports of nightmares associated with montelukast [13]. Concomitant psychiatric symptoms were insomnia, nervousness, hallucinations, aggressiveness, irritability, and anxiety [13]. Most of the patients were children aged 2 to 7 years [13]. Marchand et al. used the French database and found that sleep disorders, behavioral disorders, and depression were commonly reported in patients taking montelukast [12]. Lafay-Chebassie et al. also found four reports for depression in patients taking montelukast using the same database but in a slightly different study period [9].

A total of 31 psychiatric ADRs related to the use of montelukast were identified by Aagaard et al. in the EV database [8]. Psychiatric events were the frequent ADRs reported for montelukast and the main symptoms were nightmares and aggression [8]. Interestingly, the number of reports identified in the EV database from EU was comparatively smaller than those reported in other studies when a nation-wide database was used over a similar study period. In contrast, the study conducted by Aldea-Perona et al. using the Vigibase identified a large number of psychiatric ADRs related to the use of montelukast $(n=2630)$ when they searched the database up to 1 January, 2015 [10]. Different psychiatric symptoms were dominant in different age groups and more cases in males were reported. The most frequently reported psychiatric ADRs were sleep terror and nightmares. 
Table 2 Study characteristics of pharmacovigilance studies

\begin{tabular}{|c|c|c|c|c|c|c|}
\hline Study & Region & Data source & Study period & Inclusion criteria $^{\mathrm{a}}$ & Exposure & Results and outcomes of interest \\
\hline Biswas et al. [4] & $\begin{array}{l}\text { United } \\
\text { Kingdom }\end{array}$ & $\begin{array}{l}\text { Drug Safety Research } \\
\text { Unit }\end{array}$ & $\begin{array}{l}\text { Feb } 1998- \\
\text { Dec } 1998\end{array}$ & $\begin{array}{l}\text { ADRs } 6 \text { months following an } \\
\text { NHS prescription of } \\
\text { montelukast }\end{array}$ & Montelukast & $\begin{array}{l}\text { 1) } 250 \text { ADRs in } 191 \text { patients ( } 1.2 \% \text { of total cohort) } \\
\text { 2) NEs reported: insomnia, drowsiness, abnormal dreams, depression }\end{array}$ \\
\hline $\begin{array}{l}\text { Twaites et al. } \\
\text { [5] }\end{array}$ & $\begin{array}{l}\text { United } \\
\text { Kingdom }\end{array}$ & $\begin{array}{l}\text { Drug Safety Research } \\
\text { Unit }\end{array}$ & $\begin{array}{l}\text { Mar 1999- } \\
\text { Aug } 2001\end{array}$ & $\begin{array}{l}\text { ADRs } 6 \text { months following the } \\
\text { first NHS prescription of } \\
\text { zafirlukast }\end{array}$ & Zafirlukast & $\begin{array}{l}\text { 1) } 152 \text { ADRs in } 120 \text { patients ( } 1.5 \% \text { of total cohort) } \\
\text { 2) NEs reported: depression, anxiety, confusion, aggression, agitation } \\
\text { 3) Incidence density difference for depression }=-1.1(99 \% \mathrm{CI},-2.4-0.3)\end{array}$ \\
\hline $\begin{array}{l}\text { Wallerstadt et } \\
\text { al. [7] }\end{array}$ & Sweden & $\begin{array}{l}\text { Swedish Drug } \\
\text { Information System }\end{array}$ & $1998-2007$ & $\begin{array}{l}\text { Psychiatric ADRs in patients } \\
\text { aged }<18 \text { years using } \\
\text { montelukast }\end{array}$ & Montelukast & $\begin{array}{l}\text { 1) } 48 \text { psychiatric ADRs in } 103 \text { total ADRs of montelukast } \\
\text { 2) } 48 \% \text { of the children with psychiatric ADRs were } \leq 3 \text { years } \\
\text { 3) NEs reported: nightmares, unspecified anxiety, aggressiveness, sleep disorders, insomnia, irritability, } \\
\text { hallucination, hyperactivity, personality disorder, depressed mood, impaired concentration, amnesia }\end{array}$ \\
\hline $\begin{array}{l}\text { Bygdell et al. } \\
{[6]}\end{array}$ & Sweden & $\begin{array}{l}\text { Swedish Drug } \\
\text { Information System }\end{array}$ & $2001-2010$ & $\begin{array}{l}\text { Psychiatric ADRs in patients } \\
\text { aged }<18 \text { years of all suspected } \\
\text { medications }\end{array}$ & Montelukast & $\begin{array}{l}\text { 1) } 60 \text { ICSRs of psychiatric ADRs of montelukast } \\
\text { 2) NEs reported: sleep disorder, anxiety, hyperactivity, personality disorder, aggressiveness, suicidal } \\
\text { conditions }\end{array}$ \\
\hline $\begin{array}{l}\text { Cereza et al. } \\
{[13]}\end{array}$ & Spain & $\begin{array}{l}\text { Spanish System of } \\
\text { Pharmacovigilance }\end{array}$ & $\begin{array}{l}\text { Up to Dec } \\
2011\end{array}$ & $\begin{array}{l}\text { Psychiatric ADRs focusing } \\
\text { mainly on nightmares in } \\
\text { patients using montelukast }\end{array}$ & Montelukast & 1) NEs reported: nightmares, insomnia, nervousness, hallucinations, aggressiveness, irritability, anxiety \\
\hline $\begin{array}{l}\text { Schumock et al. } \\
\text { [11] }\end{array}$ & United States & $\begin{array}{l}\text { FDA Adverse Event } \\
\text { Reporting System } \\
\text { (FAERS) and Xponent } \\
\text { database (IMS Health, } \\
\text { Inc.) }\end{array}$ & $1999-2009$ & $\begin{array}{l}\text { Completed suicide associated } \\
\text { with LTMAs from FAERS and } \\
\text { number of dispensed } \\
\text { prescriptions from Xponent } \\
\text { database }\end{array}$ & $\begin{array}{l}\text { LTMAs } \\
\text { Comparisons: } \\
\text { SSRIs and } \\
\text { SABAs }\end{array}$ & $\begin{array}{l}\text { 1) } 105 \text { cases of completed suicides ( } 101 \text { cases for montelukast) } \\
\text { 2) Suicide rates per million prescriptions: LTMAs = } 0.50 \text { ( } 95 \% \text { CI } 0.41-0.61 \text { ); SSRIs = } 2.79 \text { (95\% CI } 2.69- \\
2.90 \text { ); SABAs = } 0.17 \text { ( } 95 \% \text { CI } 0.14-0.21 \text { ) } \\
\text { 3) } 92 \text { cases occurred following the FDA warning in } 2008 \\
\text { 4) Suicide rates per million prescriptions of LTMAs: before } 2008=0.06 \text { (95\% CI } 0.01-0.10) \text {; after } 2008= \\
1.82 \text { ( } 95 \% \text { CI } 1.47-2.23 \text { ) }\end{array}$ \\
\hline $\begin{array}{l}\text { Marchand et al. } \\
{[12]}\end{array}$ & France & $\begin{array}{l}\text { French } \\
\text { pharmacovigilance } \\
\text { database }\end{array}$ & $\begin{array}{l}20 \mathrm{Mar} \\
1998-28 \mathrm{Feb} \\
2012\end{array}$ & ADRs of montelukast & Montelukast & $\begin{array}{l}\text { 1) } 56 \text { psychiatric ADRs in } 295 \text { total ADRs of montelukast } \\
\text { 2) NEs reported: nightmares, insomnia, somnolence, aggressiveness, agitation, irritability, hyperactivity, } \\
\text { nervousness, hallucinations, depression }\end{array}$ \\
\hline $\begin{array}{l}\text { Aagaard et al. } \\
{[8]}\end{array}$ & European Union & EudraVigilance & $2007-2011$ & $\begin{array}{l}\text { ADRs in patients }<18 \text { years } \\
\text { using any asthma medications }\end{array}$ & Montelukast & $\begin{array}{l}\text { 1) } 31 \text { psychiatric ADRs in } 76 \text { total ADRs of montelukast } \\
\text { 2) NEs reported: nightmares and aggression }\end{array}$ \\
\hline $\begin{array}{l}\text { Lafay- } \\
\text { Chebassie et al. } \\
\text { [9] }\end{array}$ & France & $\begin{array}{l}\text { French } \\
\text { pharmacovigilance } \\
\text { database }\end{array}$ & $\begin{array}{l}\text { Jan } 2007- \\
\text { Dec } 2011\end{array}$ & $\begin{array}{l}\text { ADRs relating to depression of } \\
\text { all medications }\end{array}$ & Montelukast & $\begin{array}{l}\text { 1) } 4 \text { ADRs of depression in } 111 \text { total ADRs of montelukast } \\
\left.\text { 2) Reporting odds ratio }{ }^{b}=8.9 \text { (95\% CI } 3.3-24.3, p<0.001\right)\end{array}$ \\
\hline $\begin{array}{l}\text { Aldea-Perona et } \\
\text { al. [10] }\end{array}$ & Worldwide & $\begin{array}{l}\text { VigiBase from World } \\
\text { Health Organization }\end{array}$ & $\begin{array}{l}\text { Up to Jan } 1 \\
2015\end{array}$ & $\begin{array}{l}\text { Psychiatric ADRs in patients } \\
\text { aged }<18 \text { years using } \\
\text { montelukast }\end{array}$ & Montelukast & $\begin{array}{l}\text { 1) } 2630 \text { ICSRs of psychiatric ADRs in } 14670 \text { total ICSRs of montelukast } \\
\text { 2) NEs reported: suicidal behavior, anxiety, changes in physical activity, cognitive and attention disorders, } \\
\text { communication disorders, delirium (including confusion), depressed mood disorders, disturbances in } \\
\text { thinking and perception, impulse control disorders, mood disorders, personality disorders, disturbances in } \\
\text { behavior, psychiatric disorders, schizophrenia and other psychotic disorders, sleep disorders }\end{array}$ \\
\hline
\end{tabular}

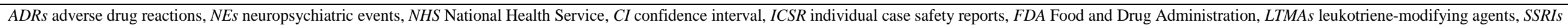
selective serotonin reuptake inhibitors, SABAs short-acting beta-agonists. ${ }^{\mathrm{a} N o}$ exclusion criteria presented in all included pharmacovigilance studies. ${ }^{\mathrm{b}} \mathrm{Case} / \mathrm{non}$-case method was used. 


\subsubsection{Case Series, Case Reports, and Reviews}

Six case reports were identified in our search in which all NEs were linked to the use of montelukast [29-34]. Only one case of suicide attempt was reported and positive de-challenge was demonstrated [32]. Other NEs identified in the case reports included hallucinations, anxiety, sleep disorders, nightmares, behavioral disturbances, aggressiveness, irritability, confusion, and attention deficit [29-34]. Delayed onset of symptoms was reported by Byrne et al. in which anxiety was diagnosed 2.5 years after starting the treatment [31]. Positive de-challenge was demonstrated in all but one case within 2 to 28 days [29-34].

Erdem et al. conducted the study using the database at a children's hospital and reported 41 psychiatric ADRs among 1024 patients using LTMAs [28]. Cheng et al. conducted a review on ADR reports related to montelukast by searching the Chinese National Knowledge Infrastructure (CNKI) and VIP database [25]. They found that five out of 18 reports were related to NEs which included psychosis, sleep disorders, irritability, suicide attempt, and attention deficit [25]. However, specific information of the case reports provided in the article was limited.

\subsubsection{Conference Abstracts}

Conference abstracts with different study designs were included for a comprehensive review. Three observational studies consisted of a relatively small sample size, ranging from 24 to 8545 subjects [38, 40, 42]. Iessa et al. did not find a significant association between suicide attempt and LTMAs [40]. Although Narang et al. did not find an association between depression and montelukast [42], Rhee et al. reported a significant increased risk of depression in patients taking LTMAs with a HR of 1.50 (95\% CI 1.02-2.21) when compared with inhaled corticosteroids in a Korean cohort [38].

Pharmacovigilance studies using databases from Spain, Italy, the United States and the WHO were conducted [35-37, 39]. Two cases of suicidal ideation were identified [36]. Gadde et al. investigated ADRs of montelukast and found that aggression was the most frequently reported ADR [35]. Aldea-Perona et al. found that all but one psychiatric ADRs were related to montelukast in a Spanish database [36]. Psychiatric ADRs were more commonly reported in males and children aged 2 to 3 years [36]. Trotta et al. also identified 88 psychiatric ADRs that were related to LTMAs in an Italian database [39].

Regarding the case reports included in the conference abstracts, two cases of hallucination with nervousness and one case of sleeping disorders related to montelukast were reported by Burgos et al. [41]. In addition, Erdem et 
al. identified three cases of seizure possibly induced by LTMAs [43]. All NEs resolved after discontinuation of the implicated medication.

\section{Discussion}

To our knowledge, this is the first comprehensive systematic review to investigate the neuropsychiatric safety of LTMAs. We include all the literature without restriction to study design or language resulting in a total of 33 included studies. After summarizing all the evidence, the potential risk of NEs associated with LTMAs cannot be ruled out with the preliminary evidence from pharmacovigilance studies, case series, and case reports. However, the quality of evidence of these study designs to evaluate such an association is not as high as RCTs and observational studies. Of the retrieved articles, only a few observational studies investigating the association between NEs and LTMAs were conducted [21-24]. Four published studies did not find an association except one conference abstract showing a significant increased risk of depression in patients taking LTMAs [21-24, 38]. However, the sample size was comparatively small. The follow-up period and covariates for adjustment were not reported in view of the limited information provided in the abstract.

The null assocaition found in the observational studies may be due to the lack of statistical power to detect the rare occurance of suicidal conditions. Still, no significant association was concluded in the post hoc analyses for other types of NEs [24]. Of note, a cohort study was published after the submission of this article for peer review [44]. A significantly higher risk of medication cessation due to NEs was reported for montelukast when compared with ICS. This is in line with the signal of NEs detected form pharmacovigilance studies.

Although the FDA issued the warning about the association in 2008 [14], there have been controversies over such an association [16-20]. Philip et al. conducted an analysis including 46 RCTs published before 2008 and no significant association was found (OR 1.12, 95\% CI 0.93-1.36) in the review [16]. Notably, the included RCTs were not designed to evaluate the association between NEs and LTMAs [14]. As rare outcomes are usually difficult to be detected in the comparatively small sample size, the evidence for the result generated from the previous review might not be adequate to support the neuropsychiatric safety of LTMAs.

Post-marketing studies conducted using different global databases demonstrate the potential association. The larger databases such as the EV from EU and the Vigibase from the WHO capture reports recorded in the nationwide systems which may lead to duplication $[8,10]$. As most of them were conducted in different periods with different outcomes of interest, these studies were all included in the narrative review to demonstrate the difference 
in reporting rates. Aldea-Perona et al. conducted a large scale pharmacovigilance study using the Vigibase which contained data from 49 countries [10]. The signal detected was further strengthened but a firm conclusion could not be drawn due to the limitations of pharmacovigilance studies. Underreporting is common but over-reporting can also occur. This is well demonstrated by the significant increase in the reporting rate of NEs after the FDA warning was issued in 2008 as indicated in the ITS analysis [26]. Therefore, the detection bias due to the warning should be investigated in future drug safety research.

In addition, covariates cannot be adjusted in pharmacovigilance studies which can lead to confounding bias [10]. Some major confounding factors are the severity and comorbidities of asthma. A review from observational studies has shown the association between asthma and suicide-related behavior [45]. Asthmatic patients are also more likely to have mental health problems including depression and anxiety disorders [46-48]. A lack of control of asthma may lead to psychological distress. Therefore, some pharmacovigilance studies included reports of ADRs of other asthma medications as comparison groups $[6,8,11]$. Despite the lack of control of confounding, using other asthma medications for comparison could provide clinical implications by comparing the rates of ADRs among different medications.

Regarding the study exposure, over half of the studies investigated NEs associated with montelukast only. Although other studies aimed to evaluate the whole drug class (LTMAs), it was acknowledged that only a few patients were on zafirlukast or zileuton $[11,22]$. Consequently, the results were mainly driven by montelukast due to its widespread use; and this may lead to a reduction of representativeness of their findings.

Of note, most of the current studies focused on children only [6-8, 10, 22, 24, 36, 37]. This could be due to the widespread use of montelukast among children; and hence, a higher reporting rate of NEs was detected. Notably, the age difference was identified by Aldea-Perona et al. as some NEs were more commonly reported in a specific age group (sleep disorders in infants aged <2 years; depression or anxiety in children aged $2-11$ years; and suicidal behavior and depression or anxiety in adolescents aged 12-17 years) [10]. However, evidence on the association between NEs and adults is limited. Although NEs resolved after the discontinuation of medications in all case reports, the long term effects of NEs on children should be further investigated given the potential association. In addition, Bydgell et al. demonstrated the sex difference by showing that aggressiveness was more prevalent in boys while sleep disorder and anxiety were more common in girls in the pediatric population aged below 18 years [6]. Aldea-Perona et al. also identified a sex difference in two studies in which both reported a higher rate of NEs in male than in female $[6,10]$. 
Although the association between NEs and LTMAs remains unclear, the possible mechanism of NEs was suggested based on animal studies and pharmacological actions of LTMAs. LTMAs mainly act by blocking the action of leukotrienes in the respiratory tracts to reduce inflammation [1-3]. Montelukast and zafirlukast are the antagonists of cysteinyl leukotriene receptor 1 (CysLT1) while zileuton is a 5-lipoxygenase inhibitor which inhibits leukotriene production [1-3]. It was hypothesized that LTMAs block CysLT1 in susceptible pediatric patients and cause NEs [49]. Conversely, several animal studies were conducted to investigate the therapeutic effect of LTMAs on Alzheimer's disease [50-53]. Leukotriene is involved in the inflammation in the brain and CysLT1 is found in the central nervous system [54]. Memory impairment was improved in animal models due to the reduction of neuroinflammation, a process potentially related to the progression of Alzheimer's disease [5053]. This may contradict the possible theory that NEs are caused by LTMAs; therefore, further studies are required to investigate the association as well as the corresponding biological action.

\subsection{Strengths and Limitations}

The inclusion of literature with different study designs and language added strengths to this review. Studies investigating different types of NEs associated with any LTMAs were included for a comprehensive review. Conference abstracts were also included to reduce publication bias. However, results from conference abstracts should be interpreted with caution as they were not subjected to peer-review before publication. Peer-reviewed publications remain to be the more robust source of data in this review. Quantification of risks was also not conducted due to the lack of RCTs and observational studies investigating the association.

\section{Conclusion}

Many pharmacovigilance studies demonstrate a potential association between NEs and LTMAs. However, RCTs and observational studies did not show a statistically significant association. High quality epidemiological studies on a larger population should be conducted to evaluate this relationship and quantify the risk of NEs with the use of LTMAs, not only in children but also in adults. Although the risk has not been confirmed, the use of LTMAs should be evaluated to balance the risks and benefits given the potential NEs of the medications. Clinicians should continue to monitor patients for NEs and report ADRs to the appropriate pharmacovigilance organization. 


\section{Compliance with Ethical Standards}

\section{Funding}

The study was partially supported by a grant from the Research Grants Council of the Hong Kong Special Administrative Region, China (Project No. HKU 789813).

\section{Conflict of Interest}

Sharon W. Y. Law, Angel Y. S. Wong, Shweta Anand, Ian C. K. Wong, and Esther W. Chan declare that they have no conflict of interest.

\section{Ethical Approval}

This article does not contain any studies with human participants or animals performed by any of the authors.

\section{Figure Captions}

Fig. 1 Review flowchart for the selection of studies. NEs neuropsychiatric events, LTMAs leukotriene-modifying agents

\section{References}

1. U.S. Food and Drug Administration (FDA). Accolate (zafirlukast) Product Label. 2013. http://www.fda.gov/Drugs. Accessed 14 November 2016.

2. U.S. Food and Drug Administration (FDA). Zyflo (zileuton) Product Label. 2012. http://www.fda.gov/Drugs. Accessed 14 November 2016.

3. U.S. Food and Drug Administration (FDA). Singulair (montelukast sodium) Product Label. 2014. http://www.fda.gov/Drugs. Accessed 14 November 2016.

4. Biswas P, Wilton L, Pearce G, Freemantle S, Sharkir S, Mann RD. Pharmacosurveillance and safety of the leukotriene receptor antagonist (LTRA), montelukast. Clin Exp Allergy Rev. 2001;1(3):300-4.

5. Twaites BR, Wilton LV, Shakir SAW. Safety of zafirlukast: Results of a postmarketing surveillance study on 7976 patients in England. Drug Saf. 2007;30(5):419-29. 
6. Bygdell M, Brunlof G, Wallerstedt SM, Kindblom JM. Psychiatric adverse drug reactions reported during a 10-year period in the Swedish pediatric population. Pharmacoepidemiol Drug Saf. 2012;21(1):79-86. 7. Wallerstedt SM, Brunlof G, Sundstrom A, Eriksson AL. Montelukast and psychiatric disorders in children. Pharmacoepidemiol Drug Saf. 2009;18(9):858-64.

8. Aagaard L, Hansen EH. Paediatric adverse drug reactions following use of asthma medications in Europe from 2007 to 2011. Int J Clin Pharm. 2014;36(6):1222-9.

9. Lafay-Chebassier C, Chavant F, Favreliere S, Pizzoglio V, Perault-Pochat MC, French Association of Regional Pharmacovigilance C. Drug-induced Depression: a Case/Non Case Study in the French Pharmacovigilance Database. Therapie. 2015;70(5):425-32.

10. Aldea-Perona A, Garcia-Saiz M, Sanz Alvarez E. Psychiatric Disorders and Montelukast in Children: A Disproportionality Analysis of the VigiBase. Drug Saf. 2016;39(1):69-78.

11. Schumock GT, Gibbons RD, Lee TA, Joo MJ, Stayner LT, Valuck RJ. The Association Between Leukotriene-Modifying Agents and Spontaneously Reported Suicide. Drug Inf J. 2012;46(1):99-106.

12. Marchand MS, Jonville-Bera AP, Autret-Leca E. Psychiatric disorders associated with montelukast: Data from the National Pharmacovigilance Database. Arch Pediatr. 2013;20(3):269-73.

13. Cereza G, Dolade NG, Laporte JR. Nightmares induced by montelukast in children and adults. Eur Respir J. 2012;40(6):1574-5.

14. U.S. Food and Drug Administration (FDA). Updated Information on Leukotriene Inhibitors: Montelukast (marketed as Singulair), Zafirlukast (marketed as Accolate), and Zileuton (marketed as Zyflo and Zyflo CR). 2015. http://www.fda.gov/Drugs. Accessed 23 December 2016.

15. Scott S GM. Singulair, Montelukast: Asthma medication linked to serious psychotic episodes in children. ABC News, Australia. 2016. http://www.abc.net.au/news/2016-09-05/asthma-tablet-linked-to-seriouspsychotic-episodes-in-children/7795474. Accessed 16 November 2016.

16. Philip G, Hustad CM, Malice MP, Noonan G, Ezekowitz A, Reiss TF et al. Analysis of behaviorrelated adverse experiences in clinical trials of montelukast. J Allergy Clin Immunol. 2009;124(4):699-706.

17. Holbrook JT, Harik-Khan R. Montelukast and emotional well-being as a marker for depression: Results from 3 randomized, double-masked clinical trials. J Allergy Clin Immunol. 2008;122(4):828-9.

18. Philip G, Hustad C, Noonan G, Malice MP, Ezekowitz A, Reiss TF et al. Reports of suicidality in clinical trials of montelukast. J Allergy Clin Immunol. 2009;124(4):691-6. 
19. Bisgaard H, Skoner D, Boza ML, Tozzi CA, Newcomb K, Reiss TF et al. Safety and tolerability of montelukast in placebo-controlled pediatric studies and their open-label extensions. Pediatr Pulmonol. 2009;44(6):568-79.

20. Schumock GT, Lee TA, Joo MJ, Valuck RJ, Stayner LT, Gibbons RD. Association between leukotriene-modifying agents and suicide: What is the evidence? Drug Saf. 2011;34(7):533-44.

21. Jick H, Hagberg KW, Egger P. Rate of suicide in patients taking montelukast. Pharmacotherapy. 2009;29(2):165-6.

22. Schumock GT, Stayner LT, Valuck RJ, Joo MJ, Gibbons RD, Lee TA. Risk of suicide attempt in asthmatic children and young adults prescribed leukotriene-modifying agents: A nested case-control study. J Allergy Clin Immunol. 2012;130(2):368-75.

23. Chen VCH, Wang TN, Liao YT, Lin TC, Stewart R, Lee CTC. Asthma and self-harm: A populationbased cohort study in Taiwan. J Psychosom Res. 2014;77(6):462-7.

24. Ali MM, O'Brien CE, Cleves MA, Martin BC. Exploring the possible association between montelukast and neuropsychiatric events among children with asthma: A matched nested case-control study.

Pharmacoepidemiol Drug Saf. 2015;24(4):435-45.

25. Cheng J. Adverse drug reactions induced by montelukast. Chin J New Drugs. 2014;23(4):486-8, 92.

26. Lu CY, Zhang F, Lakoma MD, Butler MG, Fung V, Larkin EK et al. Asthma Treatments and Mental Health Visits after a Food and Drug Administration Label Change for Leukotriene Inhibitors. Clin Ther. 2015;37(6):1280-91.

27. Zhou EH, Kaplan S, Mosholder A, Moeny D, Ding Y, Wu Y et al. Antidepressant medication dispensing among montelukast initiators. J Asthma. 2013;50(9):990-5.

28. Erdem SB, Nacaroglu HT, Unsal Karkiner CS, Gunay I, Can D. Side Effects of Leukotriene Receptor Antagonists in Asthmatic Children. Iran J Pediatr. 2015; doi:10.5812/ijp.3313

29. Anandan N, Ibitoye F. Montelukast and worsening of hallucinations in paranoid schizophrenia. Psychiatr Bull. 2008;32(7):276.

30. Skillman KL, Stumpf JL. Montelukast-induced anxiety in two pediatric patients. Pharmacotherapy. 2011;31(5):90e-5e.

31. Byrne F, Oluwole B, Whyte V, Fahy S, McGuinness D. Delayed onset of neuropsychiatric effects associated with montelukast. Ir J Psychol Med. 2012;29(2):125-7. 
32. Callero-Viera A, Infante S, Fuentes-Aparicio V, Zapatero L, Alonso-Lebrero E. Neuropsychiatric reactions to montelukast. J Investig Allergol Clin Immunol. 2012;22(6):452-3.

33. Kocyigit A, Oksuz BG, Yarar F, Uzun F, Igde M, Islek I. Hallucination development with montelukast in a child with asthma: Case presentation. Iran J Allergy Asthma Immunol. 2013;12(4):397-9.

34. Ibarra-Barrueta O, Palacios-Zabalza I, Mora-Atorrasagasti O, Mayo-Suarez J. Effect of Concomitant Use of Montelukast and Efavirenz on Neuropsychiatric Adverse Events. Ann Pharmacother. 2014;48(1):145-8. 35. Gadde DP, Creticos PS, Beakes DE, Dauby PL, Grooms LA, Abeel D et al. Adverse effects associated with leukotriene antagonist therapy. J Allergy Clin Immunol. 2010;1:AB68.

36. Aldea-Perona A, Fernandez-Quintana E, Garcia-Sanchez-Colomer M, Boada-Fernandez del Campo C, Rodriguez-Jimenez C, Sanz-Alvarez E et al. Up-to-date of the neuropsychiatric events in relation with antileukotriens-agents in the Spanish surveillance system (Sistema Espanol de Farmacovigilancia-SEFV). Basic Clin Pharmacol Toxicol. 2011;109:35.

37. Iessa N, Star K, Wilton L, Curran S, Edwards IR, Aronson JK et al. Montelukast and suicide: Causality assessment using spontaneous reports and bradford hill guidelines. Drug Saf. 2011;34:949-50.

38. Rhee CW, Choi NK, Ahn YO, Lee J, Park BJ. Risk of depression associated with use of leukotriene receptor antagonist in elderly asthma patients in Korea. Pharmacoepidemiol Drug Saf. 2011;20:S251.

39. Trotta F, Tartaglia L, Ferrazin F, Santuccio C. Psychiatric and behaviour-related adverse events occurring with antiasthmatic drugs reported in the national pharmacovigilance network. Drug Saf. 2011;34:1013-4.

40. Iessa N, Murray M, Wong I, Man K, Frank B, Santosh P et al. Leukotriene receptor antagonists and suicide: A self-controlled case series study. Drug Saf. 2013;36:855.

41. Burgos Pimentel ABP, Montoro De Francisco A, Tavakov A, Fonseca Avendano J, De Vicente Jimenez T, Chivato Perez T et al. Neuropsychiatric disorders associated with montelukast. Allergy. 2014;69:439.

42. Narang R, Narang S, Narang D, Udeani G. Contemporary use of montelukast and its association with depression in asthma and allergic rhinitis patients. Chest. 2014;146(4):13A.

43. Erdem SB, Karaman S, Nacaroglu HT, Unsal Karkiner CS, Can D. Are leukotriene receptor antagonists safe? Allergy. 2015;70:412-3. 
44. Benard B, Bastien V, Vinet B, Yang R, Krajinovic M, Ducharme FM. Neuropsychiatric adverse drug reactions in children initiated on montelukast in real-life practice. Eur Respir J. 2017; doi:10.1183/13993003.00148-2017

45. Iessa N, Murray ML, Curran S, Wong IC. Asthma and suicide-related adverse events: a review of observational studies. Eur Respir Rev. 2011; doi:10.1183/09059180.00005211

46. Trojan TD, Khan DA, Defina LF, Akpotaire O, Goodwin RD, Brown ES. Asthma and depression: the Cooper Center Longitudinal Study. Ann Allergy Asthma Immunol. 2014; doi:10.1016/j.anai.2014.02.015

47. Goodwin RD, Robinson M, Sly PD, McKeague IW, Susser ES, Zubrick SR et al. Severity and persistence of asthma and mental health: a birth cohort study. Psychol Med. 2013;

doi:10.1017/s0033291712001754

48. Goodwin RD, Scheckner B, Pena L, Feldman JM, Taha F, Lipsitz JD. A 10-year prospective study of respiratory disease and depression and anxiety in adulthood. Ann Allergy Asthma Immunol. 2014; doi:10.1016/j.anai.2014.08.003

49. Calapai G, Casciaro M, Miroddi M, Calapai F, Navarra M, Gangemi S. Montelukast-induced adverse drug reactions: A review of case reports in the literature. Pharmacology. 2014;94:60-70.

50. Zhang CT, Lin JR, Wu F, Ghosh A, Tang SS, Hu M et al. Montelukast ameliorates streptozotocininduced cognitive impairment and neurotoxicity in mice. Neurotoxicology. 2016;57:214-22.

51. Kalra J, Kumar P, Majeed ABA, Prakash A. Modulation of LOX and COX pathways via inhibition of amyloidogenesis contributes to mitoprotection against beta-amyloid oligomer-induced toxicity in an animal model of Alzheimer's disease in rats. Pharmacol Biochem Behav. 2016;146-147:1-12.

52. Lai J, Hu M, Wang H, Hu M, Long Y, Miao MX et al. Montelukast targeting the cysteinyl leukotriene receptor 1 ameliorates Abeta1-42-induced memory impairment and neuroinflammatory and apoptotic responses in mice. Neuropharmacology. 2014;79:707-14.

53. Di Meco A, Lauretti E, Vagnozzi AN, Pratico D. Zileuton restores memory impairments and reverses amyloid and tau pathology in aged Alzheimer's disease mice. Neurobiol Aging. 2014;35(11):2458-64.

54. Ghosh A, Chen F, Thakur A, Hong H. Cysteinyl Leukotrienes and Their Receptors: Emerging Therapeutic Targets in Central Nervous System Disorders. CNS Neurosci Ther. 2016; doi:10.1111/cns.12596 